\title{
Estimation of humoral immune response in rabbits fed with Cucurbita maxima seeds
}

\author{
V. Ranganathan, S. Selvasubramanian and S. Vasanthakumar
}

Department of Pharmacology and Toxicology,

Madras Veterinary College, Tamil Nadu Veterinary and Animal Sciences University, Chennai, Tamil Nadu, India

Corresponding author: V. Ranganathan, email:varanganathan@gmail.com

Received: 13-11-2012, Accepted: 24-12-2012, Published online: 12-04-2013

\section{How to cite this article:}

Ranganathan V, Selvasubramanian S and Vasanthakumar S (2013) Estimation of humoral immune response in rabbits fed with Cucurbita maxima seeds, Vet World 6(7):396-399, doi: 10.5455/vetworld.2013.396-399

\begin{abstract}
Aim : The objective of the study was to estimate the humoral immune response in rabbits treated with Cucurbita maxima seeds.

Materials and Methods: Thirty six male Newzealand White rabbits were divided into six groups (I, II, III, IV, V, VI) of six in each. Group I was the untreated control. Group II was treated with dexamethasone sodium ( $2 \mathrm{mg} / \mathrm{Kg}$, i.m) for 7 days. Group III was treated with levamisole hydrochloride at $2.5 \mathrm{mg} / \mathrm{kg}$ (s.c) thrice a week. Group IV was treated with Cucurbita maxima seeds. Group V was treated with levamisole and dexamethasone and Group VI was treated with dexamethasone and Cucurbita maxima seeds. The seed was given @ $1000 \mathrm{mg} / \mathrm{kg}$ orally for 10 days. Antibody titre and serum immunoglobulin concentration were estimated along with haematology.
\end{abstract}

Results: Dexamethasone caused significant decreases in the antibody titre, immunoglobulin concentration where as Curcurbita maxima, Dexamethasone + Curcurbita maxima and dexamethasone + levamisole groups showed significant increase in these entities. There were no significant differences in RBC count, Haemoglobin contents among all the groups studied.

Conclusion: Results suggest that Cucurbita maxima seeds has the ability to stimulate humoral immune response in rabbits.

Keywords : Cucurbita maxima, dexamethasone, levamisole Hcl, rabbit

\section{I ntroduction}

Several herbs have been used traditionally to prevent and treat human and animal diseases. Recently, scientific evaluation of plants and preparations of plant origin medications have received more attention [1]. One of these plants is Cucurbita maxima, popularly known as pumpkin is cultivated throughout the world for use as vegetable as well as medicine. It has been used traditionally as medicine in many countries such as India, China, Argentina, Brazil and Iran [2]. The seeds of Cucurbita maxima contain necessary fatty acids, vitamin A and C, Calcium and Zinc [3]. Pumpkin has been tried successfully for its antioxidant, antimalarial, antitumour, anti-inflammatory, antibacterial, anti fungal cardioprotective and anthelmintic properties [4-11]. Pumpkin seed has been used in traditional medicine in North America and Mexico since long as an antihelmintic agent and for supportive treatment in functional disorders of the bladder and for difficulties in urination $[12,13]$. Stimulation of the immune system is highly desirable for the treatment of immunodeficiency and infectious diseases [14]. The anti-inflammatory and cardio protective effects of pumpkin may relate to an influence of plant compounds on immunocompetent cells. The evaluation of immune

This article is an open access article licensed under the terms of the Creative Commons Attribution License (http://creativecommons. org/licenses/by/2.0) which permits unrestricted use, distribution and reproduction in any medium, provided the work is properly cited. response of Cucurbita maxima seeds may benefit human and animal population in case of infectious conditions. The present study was undertaken to find out the effect of Cucurbita maxima seeds on the humoral immune response in rabbits.

\section{Materials and Methods}

Thirty six male Newzealand White rabbits with the bodyweight of 1000-1500g were divided into six groups (I, II, III, IV, V, VI) of six in each. Group I was the untreated control. Group II was treated with dexamethasone sodium (Immunosuppressive). Group III was treated with levamisole hydrochloride (Immuno stimulant). Group IV was treated with Cucurbita maxima seeds (shade dried crude powder preparation). Group V was treated with levamisole and dexamethasone and Group VI was treated with dexamethasone and Cucurbita maxima seeds.

The rationale behind the use of Cucurbita maxima with dexamethasone was to study the influence of Cucurbita maxima seed on dexamethasone induced immunosuppression status of rabbits [1,15]. For comparison, dexamethasone was given with levamisole (Group IV) as the latter is known to restore corticosteroid induced depletion of Lymphocytes. Levamisole $\mathrm{Hcl}$ was given at $2.5 \mathrm{mg} / \mathrm{kg}$ subcutaneously thrice a week, dexamethasone sodium was given at $2 \mathrm{mg} / \mathrm{kg}$ intra muscularly for seven days and Cucurbita maxima was given@ $1000 \mathrm{mg} / \mathrm{kg}$ orally for 10 days. 
Table-1. Effect of immunomodulators on antibody titre (Mean \pm SEM)

\begin{tabular}{|c|c|c|c|c|c|c|}
\hline Groups & & 0 day & 7th day & 14th day & 21st day & Groups Means \\
\hline Control & I & 0.00 & $52.54 \pm 0.02$ & $076.06 \pm 0.06$ & $096.07 \pm 0.06$ & $056.17^{c} \pm 0.03$ \\
\hline Dexamethasone & ॥ & 0.00 & $10.00 \pm 4.47$ & $020.00 \pm 0.00$ & $026.67 \pm 04.22$ & $014.17^{d} \pm 2.17$ \\
\hline Levamisole & III & 0.00 & $73.33 \pm 6.67$ & $133.33 \pm 16.87$ & $213.33 \pm 33.73$ & $105.00^{b} \pm 61.27$ \\
\hline Cucurbita maxima & IV & 0.00 & $93.33 \pm 22.31$ & $226.67 \pm 43.41$ & $293.33 \pm 26.67$ & $153.33^{a} \pm 23.09$ \\
\hline $\begin{array}{l}\text { Dexamethasone + } \\
\text { Levamisole }\end{array}$ & $\mathrm{V}$ & 0.00 & $120 \pm 17.89$ & $293.33 \pm 26.67$ & $320.00 \pm 71.55$ & $183.33^{\mathrm{a}} \pm 29.02$ \\
\hline $\begin{array}{l}\text { Dexamethasone + } \\
\text { Cucurbita maxima }\end{array}$ & VI & 0.00 & $120 \pm 17.89$ & $213.33 \pm 33.73$ & $346.67 \pm 64.22$ & $170.00^{a} \pm 29.08$ \\
\hline
\end{tabular}

Values (Mean \pm S.E.M., $n=6$ ) in the same column bearing no superscript common vary significantly $(P \leq 0.01)$

Table-2. Effect of immunomodulators on total serum immunoglobulin levels (Mean $\pm \mathrm{SEM}$ ) $\mathrm{mg} / \mathrm{ml}$

\begin{tabular}{|c|c|c|c|c|c|c|}
\hline Groups & & 0 day & 7th day & 14th day & 21st day & Groups Means \\
\hline Control & I & $32.24 \pm 0.09$ & $33.01 \pm 0.23$ & $33.25 \pm 0.02$ & $33.27 \pm 0.04$ & $32.94^{d} \pm 0.01$ \\
\hline Dexamethasone & ॥ & $32.35 \pm 0.32$ & $31.78 \pm 0.16$ & $32.92 \pm 0.05$ & $32.50 \pm 0.28$ & $32.39^{e} \pm 0.19$ \\
\hline Levamisole & III & $33.08 \pm 0.25$ & $35.63 \pm 0.19$ & $35.74 \pm 0.17$ & $36.56 \pm 0.53$ & $35.25^{c} \pm 0.28$ \\
\hline Cucurbita maxima & IV & $33.19 \pm 0.23$ & $39.97 \pm 0.13$ & $43.63 \pm 0.16$ & $48.94 \pm 0.09$ & $41.43^{a} \pm 0.15$ \\
\hline $\begin{array}{l}\text { Dexamethasone + } \\
\text { Levamisole }\end{array}$ & $\mathrm{V}$ & $33.10 \pm 0.29$ & $40.41 \pm 0.20$ & $44.39 \pm 0.16$ & $47.70 \pm 0.17$ & $41.40^{a} \pm 0.21$ \\
\hline $\begin{array}{l}\text { Dexamethasone + } \\
\text { Cucurbita maxima }\end{array}$ & VI & $33.03 \pm 0.17$ & $38.10 \pm 0.06$ & $43.84 \pm 0.14$ & $48.15 \pm 0.14$ & $40.78^{b} \pm 0.13$ \\
\hline
\end{tabular}

Values (Mean \pm S.E.M., $n=6$ ) in the same column bearing no superscript common vary significantly $(P \leq 0.01)$

Table-3. Effect of immunomodulators on haematological parameters (Mean \pm SEM)

\begin{tabular}{|c|c|c|c|c|}
\hline Groups & & Total RBC (X10 $10^{6}$ umm) & $\mathrm{Hb}(\mathrm{g} / \mathrm{dl})$ & Total WBC (cumm) \\
\hline Control & I & $5.88 \pm 0.02$ & $12.29 \pm 0.06$ & $7873.79^{b} \pm 22.65$ \\
\hline Dexamethasone & ॥ & $5.82 \pm 0.03$ & $12.15 \pm 0.10$ & $7354.42^{c} \pm 31.79$ \\
\hline Levamisole & III & $5.89 \pm 0.03$ & $12.32 \pm 0.12$ & $7902.96^{b} \pm 53.15$ \\
\hline Cucurbita maxima & IV & $5.85 \pm 0.02$ & $12.34 \pm 0.04$ & $7853.46^{\mathrm{b}} \pm 25.39$ \\
\hline $\begin{array}{l}\text { Dexamethasone + } \\
\text { Levamisole }\end{array}$ & $\mathrm{V}$ & $5.90 \pm 0.04$ & $12.30 \pm 0.10$ & $8034.67^{\mathrm{a}} \pm 49.46$ \\
\hline $\begin{array}{l}\text { Dexamethasone + } \\
\text { Cucurbita maxima }\end{array}$ & VI & $5.90 \pm 0.05$ & $12.33 \pm 0.03$ & $8013.83^{\mathrm{a}} \pm 29.90$ \\
\hline
\end{tabular}

Values (Mean \pm S.E.M., $n=6$ ) in the same column bearing no superscript common vary significantly $(P \leq 0.01)$

Ethical approval: The study was carried out after getting approval from Institutional Animal Ethical Committee.

All the six groups of rabbits were immunized with typhoid-H antigen at the dose of one ml subcutaneously on $1^{\text {st }}$ day and $15^{\text {th }}$ day. Blood was collected and serum separated on day $0,7,14$ and 21 for the estimation of antibody titre and total serum immunoglobuline levels. For estimation of anibody titre, widal tube agglutination test was performed using widal test kits (Span Diagnostics Ltd, Surat, India).

Estimation of total serum immunoglobulin: It was carried out by ammonium sulphate precipitation and dialysis method [16]. $5 \mathrm{ml}$ of saturated ammonium sulphate solution was added slowly to $5 \mathrm{ml}$ serum in a test tube to get half saturation of ammonium sulphate in the sample. The contents were mixed continuously by swirling the tube without agitating excessively. The mixture was allowed to stand for 5 minutes so that globulin precipitates. The material was centrifuged for 10 minutes at high speed. The precipitate was allowed to settle down at the bottom of the tube. The supernatant fluid (containing albumin) was poured off and the precipitate was redissolved in $1 \mathrm{ml}$ distilled water. The dissolved precipitate was put in a semi permeable cellophane tube, and each end of tube was tied in a distilled water beaker. The distilled water was frequently changed to dialyse out ammonium sulphate ions completely. The contents of the cellophane tube were dissolved in $5 \mathrm{ml}$ of normal saline. The globulin concentration was measured spectrophotometrically and the O.D. values obtained were multiplied by 0.70 .

Total erythrocyte count (RBC): It was done by Hayem's dilution method. Haemoglobulin $(\mathrm{Hb})$ estimation was done by Sahil's acid haematin method. Total leukocyte count (WBC) was done by standard dilution method.

Statistical analysis: The data obtained were statistically analysed as per method of Snedecor, G.W. and Cochran,W.G. [17].

\section{Results}

Dexamethasone caused significant decrease in the antibody titre $(14.17 \pm 2.17)$ when compared to all other groups. Groups treated with Curcurbita maxima, Dexamethasone + Curcurbita maxima and dexamethasone + levamisole groups showed significant increase in antibody titre $(153.33 \pm 23.09,170 \pm 29.08,183.33 \pm$ 29.02 , respectively) and the results were comparable among each other (Table-1).

The dexamethasone treated group showed significant decrease in total serum immunoglobulin level when compared to all other groups. Groups 
treated with dexamethasone + Levamisole, Cucurbita maxima and dexamethasone + Cucurbita maxima showed significant increase in the total serum immunoglobulin levels $(41.40 \pm 0.21 \mathrm{mg} / \mathrm{ml}, 41.43 \pm 0.15 \mathrm{mg} / \mathrm{ml}, 40.78$ $\pm 0.13 \mathrm{mg} / \mathrm{ml}$ respectively) (Table-2). There were no significant differences in total erythrocyte count, haemoglobin contents among all the groups studied where as significant reduction in the levels of total leukocyte count was observed in dexamethasone treated group (Table-3).

\section{Discussion}

In the present study, dexamethasone produced a significant reduction in antibody titre when compared to control which is in accordance with the findings of Pruett et al [18]. Levamisole produced significant increase in titre when compared to control and was able to overcome the dexamethasone suppressed antibody titre. Similar results were obtained by Babiuk and Mishra [19]. Cucurbita maxima was able to produce a significant increase in the antibody titre both in normal and suppressed animals. The effect of Cucurbita maxima is almost comparable with that of levamisole. Ocimum sanctum has also shown increased antibody titre in rats when challenged with typhoid $\mathrm{H}$ antigen [20]. The inhibitory effect produced by dexamethasone on the immunoglobulin concentration is in accordance with Anderson et al [21].

The effect of levamisole on immunoglobulin level in control and immune suppressed animals are prominent. Ascorbic acid, a water soluble vitamin also produced similar effect on total immunoglobulin level in rabbits challenged with typhoid $\mathrm{H}$ antigen [22]. Cucurbita maxima was able to restore the immunoglobulin level in immune suppressed animals and the effects were comparable to levamisole and this effect could be due to the presence of ascorbic acid in Cucurbita maxima. Steroid induced immunosuppression model is optimistic in rabbits based on the changes in the lymphocyte subset distribution, changes in proliferative capacity of lymphocytes and activity of neutrophils produced by steroids. In another study, concanavalin A stimulated the proliferative capacity of lymphocytes in thymus significantly when suppressed with dexamethasone in rabbits [23]. Levamisole and Cucurbita maxima restored the effects produced by dexamethasone in the study. The improved immunity in the immunosuppressed model as compared to individual treatments might be due to the increased expression of immune factors in the presence of dexamethasone. Levamisole and Punica granatum restored the immunosuppressed effects of dexamethasone in an identical experimental setting [15]. Dexamethasone produced neutrophilia and decrease in leukocyte count when compared to all other groups. This is in accordance with the findings of Wilkie et al [24]. There were no changes in RBC and hemoglobin contents among different groups where as Cucurbita maxima and levamisole could increase total WBC count significantly in rabbits, immunosuppressed with dexamethasone sodium.

\section{Conclusion}

The results of the study suggest that Cucurbita maxima seed powder has the ability to modulate humoral immune response in normal and immunosuppressed rabbits.

\section{Authors' contribution}

All authors contributed equally. All authors read and approved the final manuscript.

\section{Acknowledgements}

This study is a part of M.V.Sc thesis submitted by the first author to Tamil Nadu Veterinary and Animal Sciences University (TANUVAS). The author is thankful to TANUVAS for providing the facilities to carry out the study.

\section{Competing interests}

Authors declare that they have no competing interest.

\section{References}

1. Jafarian, A., Zolfaghari, B. and Parnianifard, M. (2012) The effects of methanolic, chloroform and ethylacetate extracts of the Curcurbita pepo L. on the delayed type hypersensitivity and antibody production. Research in Pharmaceutical Sciences 7 (4) : 217-224.

2. Adolfo, A.C. and Michael, H. (2007) Mexican plants with hypoglycaemic effect used in the treatment of diabetes. J.Ethnopharmacol 99:325-348.

3. Ravi Shankar, K., Kiranmayi, G.V.N., Appa Reddy, G.V., Savjanya, V.V.L., Baba Sainadh, V., Lakshmi Durga, V.G., Siva Prasad, V., Swami Naidu, P.V. and Prasad, T.(2012) Preliminary phytochemical screening and in vitro anti bacterial activity of cucurbita seed extract. International Journal of Research in Pharmacy and Chemistry 2 (1): 8691.

4. Ito, Y., Maeda, S., and Sugiyama, T. (1986) Suppression of 7, 12-dimethylbenz [a] anthracene-induced chromosome aberrations in rat bone marrow cells by vegetable juices. Mutat Res. 172:55-60.

5. Hongjian, Z., Xunyi, N. and Giangong, D. (1999) Experimental study of the effect of Sophora flavescens Ait and Cucrbita pepo L. on benign prostatic hyperplasia. Chin J Surg Intergrated Tradit West Med. 72:42-50.

6. Liu, T., Zhang, M., Zhang, H., Sun, H., Yang, X., Deng, Y. and Ji, W.(2008) Combined antitumor activity of cucurbitacin B and docetaxel in laryngeal cancer. Eur $J$ Pharmacol.587:78-84.

7. Fahim, A.T., Abd-el Fattah, A.A., Agha, A.M. and Gad, M.Z.(1995) Effect of pumpkin-seed oil on the level of free radical scavengers induced during adjuvant-arthritis in rats. Pharmacol Res. 31:73-79.

8. Zuhair, H.A., Abd El-Fattah, A.A. and El-Sayed, M.I. (2002) Pumpkin-seed oil modulates the effect of felodipine and captopril in spontaneously hypertensive rats. Pharmacol Res. 41:555-563.

9. Vassiliou, A.G., Neumann, G.M., Condron, R..and Polya, G.M. (1998) Purification and mass spectrometry-assisted sequencing of basic antifungal proteins from seeds of pumpkin (Cucurbita maxima). Plant Sci. 134:141-162.

10. Escandell, J.M., Kaler, P., Recio, M.C., Sasazuki, T., Shirasawa, S.and Augenlicht, L. (2008) Activated kRas protects colon cancer cells from cucurbitacin induced apoptosis: The role of p53 and p21. Biochem Pharmacol. 76:198-207.

11. Chan, T.K., Li, K., Lam, Liu S., Chu, K.H., Toh, M. and Xie, W.D.(2010) Cucurbitacin B inhibits STAT3 and the Raf/MEK/ERK pathway in leukemia cell line K562. Cancer 
Lett. 289: 46-52.

12. Srivastava, M.C. and Singh S.W. (1967) Anthelmintic activity of Cucurbita maxima (kaddu) seeds. Indian J. Med. Res. 55: 629-32.

13. Winkler, C., Wirleitner, B., Schroecksnadel, K., Schennach, H. and Fuchs, D. (2005) Extracts of pumpkin (Cucurbita pepo L.) seeds suppress stimulated peripheral blood mononuclear cells in vitro. Am. J. Immunol 1(1): 6-11.

14. Koko, W.S., Mesaik, M.A., Yousaf, S., Galal, M. and Choudhary M.I. (2008) In vitro immunomodulating properties of selected Sudanese medicinal plants, J Ethnopharmacol. 118:26-34.

15. Ross, R.G., Selvasubramanian, S. and Jayasundar, S. (2001)Immunomodulatory activity of Punica granatum in Rabbits. J.Ethnopharmacol.78: 85-87.

16. Talwar. and Gupta, P. (1983) A handbook of practical immunology. Vikas Publishing house Pvt. Ltd., New Delhi.

17. Snedecor,G.W. and Cochran,W.G. (1994) Statistical methods, $6^{\text {th }}$ Edition, IOWA State Universtiy press, Ames, IOWA.

18. Pruett, J.H., Fisher,W.F and Deloach,J.R. (1987) Effects of dexamethasone on selected parameters of the bovine immune system. Vet. Res. Commun. 11:305-323.

19. Babiuk, L.A. and Misra, V. (1981) Levamisole and bovine immunity: in vitro and in vivo effects on immune responses to herpes virus immunization. Can.J.Microbiol. 22:1312-1319.

20. Savitri, J. L., Godhwani. and Vyas, D. S. (1988) Cassia occidentalis, ocimum sanctum. A preliminary study evaluating is immunoregulatory profile in albino rats. J.Ethnopharmacol.24:193-198.

21. Anderson, B. H., Watson, D. L. and Colditz, I.G. (1999) The effect of dexamethasone on some immunological parameters in cattle. Vet. Res. Commun 23(7):399-413.

22. Ansari, K.V., Kastury, N.. Tewarson, S.L., Singh, S. and Pandey, R.C. (1998) An experimental and clinical evaluation of immunomodulating potential of ascorbic acid. Indian $J$. Pharmacol 30:94-96.

23. Jeklova, E.,Leva, L.,Jaglic, Z. and Faldyna, M. (2008) Dexamethasone induced immune suppression: A rabbit model. Vet. Immunol. Immunopathol.15:231-40.

24. Wilkie, B.N., Caoili, F. and Jacobs, R. (1979) Bovine lymphocytes Erythrocyte rosettes in normal lymphomatous and corticosteroid-treated cattle. Can. J. Comp. Med. 43: 2228.

$* * * * * * * *$ 